Article

\title{
Secondary Organic Aerosol Formation from Nitrophenols Photolysis under Atmospheric Conditions
}

\author{
Iustinian Gabriel Bejan ${ }^{1,2}, * \mathbb{D}$, Romeo-Iulian Olariu ${ }^{1,2}$ and Peter Wiesen ${ }^{3}$ \\ 1 Department of Chemistry, Faculty of Chemistry, "Alexandru Ioan Cuza” University of Iasi, \\ 11 Carol I, 700506 Iasi, Romania; oromeo@uaic.ro \\ 2 Integrated Centre of Environmental Science Studies in the North Eastern Region, \\ "Alexandru Ioan Cuza" University of Iasi, 11 Carol I, 700506 Iasi, Romania \\ 3 Institute for Atmospheric and Environmental Research, Bergische Universität Wuppertal, \\ 42097 Wuppertal, Germany; wiesen@uni-wuppertal.de \\ * Correspondence: iustinian.bejan@uaic.ro; Tel.: +44-023-220-1344
}

Received: 19 October 2020; Accepted: 10 December 2020; Published: 11 December 2020

\begin{abstract}
Nitrophenols are important products of the aromatic compounds photooxidation and play a considerable role in urban chemistry. Nitrophenols are important components of agricultural biomass burning that could influence the climate. The formation of secondary organic aerosol from the direct photolysis of nitrophenols was investigated for the first time in a quartz glass simulation chamber under simulated solar radiation. The results from these experiments indicate rapid SOA formation. The proposed mechanism for the gas-phase degradation of nitrophenols through photolysis shows the formation of biradicals that could react further in the presence of oxygen to form low volatile highly oxygenated compounds responsible for secondary organic aerosol formation. The inhibiting effect of $\mathrm{NOx}$ and the presence of an $\mathrm{OH}$ radical scavenger on the aerosol formation were also studied. For 2-nitrophenol, significant aerosol formation yields were observed in the absence of an $\mathrm{OH}$ radical scavenger and NOx, varying in the range of $18 \%-24 \%$. A gas-phase/aerosol partitioning model was applied assuming the presence of only one compound in both phases. A degradation mechanism is proposed to explain the aerosol formation observed in the photolysis of nitrophenols. The atmospheric impact of nitrophenol photolysis is discussed and the importance for atmospheric chemical models is assessed.
\end{abstract}

Keywords: nitrophenol; gas-phase photolysis; secondary organic aerosol; NOx effect; $\mathrm{OH}$ radical scavenger effect; gas-particle partition model

\section{Introduction}

A complex mixture of volatile organic compounds (VOC) of anthropogenic and biogenic origin is present in the atmosphere at different mixing ratios [1]. Atmospheric oxidants, temperature, and solar radiation drive the physical and chemical processes taking place in the atmosphere, which can be considered as a photochemical reactor. The reactions and processes occurring within the troposphere have an impact on climate, ecosystems, and human health, affecting mankind's habitability. A strong anthropogenic influence has occurred over the last decades on tropospheric gas and particle composition. Molecules present in the atmosphere may have a considerable effect on the environment even at very low concentrations. Once present in the atmosphere, VOCs can undergo chemical transformations into new, mostly higher oxidized compounds of lower volatility and bigger molecular mass [2,3].

Aromatic hydrocarbons are an important class of VOCs mainly present in the urban atmosphere as a result of anthropogenic activities [4]. They are responsible for secondary organic aerosol (SOA) 
formation [4], and up to $30 \%$ of photo-oxidant formation [5,6]. Very recently, they have been considered to play an important role also in the increasing acidity of the atmosphere [7]. In the gas phase, the chemical degradation of aromatic hydrocarbons is initiated mainly by $\mathrm{OH}$ radical reactions. However, hydroxylated aromatic compounds and those that have unsaturated substituents on the aromatic ring could also react with $\mathrm{NO}_{3}$ radicals and ozone $[4,8]$. Further photooxidation of aromatic compounds is well known to produce semivolatile organic compounds (SVOC), low (LVOC) and extremely low volatile organic compounds (ELVOC) $[9,10]$. Photolysis has been found to be an important removal process for a few classes of aromatic compounds under atmospheric conditions: nitrophenols [11,12], nitrogen-containing heterocyclic compounds, and nitro polycyclic aromatic hydrocarbons $[13,14]$.

The role of aerosols on climate and atmospheric chemistry has attracted considerable interest over the last decades [1,2]. A specific property of aerosols is their role in cloud droplet formation [15]. Aerosols present in the atmosphere can scatter, reflect, or absorb solar radiation. [16]. Research studies on SOA formation from the photooxidation of aromatic compounds have been focused mainly on the chemical degradation of benzene and toluene $[9,10,17]$. Although it is well established that aromatic compounds contribute to SOA formation, the dynamic degradation mechanism preceding aerosol formation and evolution is still unclear.

Nitroaromatics have been detected in the environment by Nojima et al. (1975), who detected nitrophenols in rainwater [18]. Studies on the atmospheric chemistry of nitroaromatics revealed their phytotoxic properties and possible contribution to tree leaves degradation $[19,20]$. Nitrophenols are of particular interest since they have been identified in the air [21,22], water [23], fog [24], rain [25], clouds [26], soil [27], and snow [28].

Nitrophenols and nitrocresols are present in vehicle exhaust as a result of engine internal combustion [29] but could be also emitted from coal and wood combustion, dyes and explosives, disinfectants, and pharmaceuticals industries [22]. Nitrophenols have been identified and quantified as gas-phase products from the $\mathrm{OH}$ and $\mathrm{NO}_{3}$ radical initiated oxidation of phenols and cresols [8,30-33]. Nitrophenols, once present in the troposphere, would further react with $\mathrm{OH}$ radicals or photolyze under solar radiation but could also partition between gas/aqueous phases. An aggregated concentration level of nitrophenols has been reported at $\sim 0.03 \mathrm{ppbv}$; however, in the polluted urban atmosphere, up to $20 \mathrm{ppbv}$ of total nitrated phenolic compounds have been reported [22,34]

Studies on chemical processes relevant for the atmosphere are performed in the well-equipped simulation chambers [35]. Kinetic investigations on the photolysis of nitrophenols have been performed in QUAREC chamber. Additionally, the authors also measured the $\mathrm{OH}$ radical reaction rate coefficients for a series of methylated 2-nitrophenolsand suggested gas-phase photolysis as the main sink of nitrophenols in the atmosphere [12]. Olariu et al. (2002), observed nitro-methylated phenols as products of the $\mathrm{OH}$ radical initiated photooxidation of methylated phenols/NOx mixtures [8]. Nitrate radical reactions with phenols and cresols are also sources of nitrophenols and nitrocresols in the atmosphere $[31,32,36]$. Olariu et al. (2013) suggested a reaction mechanism that involves the initial formation of the "ipso" adduct, then decomposition via H-atom abstraction with phenoxy radical formation finally leading to nitrophenol as reaction product in the presence of $\mathrm{NO}_{2}$ [36]. Studies performed by Alif et al. (1991) in the liquid phase have shown that the photolysis of nitrophenols might be relevant for the atmosphere [37]. Later, additional studies support these findings [14,22,38]. Nitrophenols, absorbing light and reducing the actinic flux, could be considered to decrease the oxidizing capacity of the atmosphere and slow down photochemical reactions [38]. However, as a HONO formation contributor through its photolysis, nitrophenols increase the concentration of the oxidants in the atmosphere [11].

A series of photolysis experiments of 2-nitrophenol and 2-nitro-p-cresol (4-methyl-2-nitrophenol) have been performed in the QUAREC quartz glass chamber in order to determine their photolytic potential for SOA formation and also to gain more information about the effect of $\mathrm{NOx}$ and an $\mathrm{OH}$ radical scavenger on SOA formation yields. Previous studies have already proven that photolysis is 
the main degradation pathway for nitrophenols in the atmosphere [12]. Bardini et al. (2004) studied SOA formation in single photolysis experiments for 2-nitrophenol and a few of methylated isomers in the large EUPHORE chamber as part of a PhD work [39]. The study from Bardini was performed in the presence of a small initial amount of NOx resulting from chamber background and in the absence of an OH radical scavenger [40]. Martin-Reviejo and Wirtz (2005) have suggested nitrophenols as precursors for aerosol formation in the $\mathrm{OH}$ radical initiated photooxidation of benzene, toluene, and xylenes [17]. However, their key role in aerosol formation is still unclear.

To improve our understanding of the nitrophenol photolysis as a source of atmospheric HONO and further $\mathrm{OH}$ radicals, the influence of an $\mathrm{OH}$ scavenger and the irradiation intensity on SOA formation were investigated. Qualitative information regarding the aerosol yield was obtained using a gas/aerosol absorption model. Possible atmospheric implications of the observations are discussed. The present work will complete the investigations on the nitrophenol atmospheric behavior, adding important input on the contribution of this important class of semivolatile organic compounds to SOA formation in the urban area, highlighting the importance of studying new possible mechanisms leading to particle formation in the atmosphere.

\section{Experiments}

\subsection{Chamber Description and Equipments}

Investigations on the SOA formation were performed in the QUAREC 10801 quartz glass reactor described previously [41]. The reactor is built up by a connection of two quartz glass tubes with a wall thickness of $5 \mathrm{~mm}$ and an inner diameter of $47 \mathrm{~cm}$. The reactor has a total length of $6.2 \mathrm{~m}$. The tubes are closed at both ends with two enameled aluminum flanges. The pumping system used for evacuation to an end vacuum of $10^{-3}$ mbar is ensured by a turbo molecular pump system (Leybold-Heraeus PT 450 C) connected to the reactor via a central flange ring. The reactor temperature is monitored by a PT-100 temperature sensor. Teflon blades mixing fans are used for mixing inside the reactor and sampling of gases and particles are performed with Teflon and steel sampling lines. The collection sampling tubes are connected to secondary organic aerosol measurement tools, gas monitors, and gas-chromatography analytical instruments. The inlets and outlets from both closing flanges are linked with specific analytical instrumentation for gas and particle monitoring. The compensation pressure inside the reactor is performed by a calibrated mass flow controller when sampling collection procedures require high volume samples.

The solar light is simulated inside the chamber by using 32 lamps (Philips TL05-40W super actinic) that emit in the range of 300-480 nm with maxima at $360 \mathrm{~nm}$. The lamps are mounted around the reaction vessel and could be switched alternatively by packs of eight to ensure different levels of irradiation. All the experiments performed in the QUAREC chamber are temperature controlled at any level in the range of $283-313 \mathrm{~K}$.

Gas-phase reactants and products were measured inside the reaction chamber employing an FT-IR (Fourier Transform Infrared) spectrometer placed at one end of the chamber and coupled inside the reactor through $\mathrm{KBr}$ windows via a gold-coated mirror system. The White-type, multiple-reflection mirror system (base path length $5.91 \pm 0.01 \mathrm{~m}$ ) drives the infrared beam into the reactor using 82 traverses, which is equivalent to a total optical path length of $484.7 \pm 0.8 \mathrm{~m}$. A Globar IR light source was used for the FTIR spectrometer. The spectral resolution of $1 \mathrm{~cm}^{-1}$ was used for the recorded spectra of the compounds in this study. The FT-IR spectrometer (NICOLET NEXUS) used in this work was equipped with liquid nitrogen cooled mercury-cadmium-tellurium (MCT) detector.

The formation of SOA from the photolysis of nitrophenols in the QUAREC chamber was investigated with a Scanning Mobility Particle Sizer (SMPS) system. The SMPS consists of an electrostatic classifier TSI $3071 \mathrm{~A}$ and a particle counter TSI 3022 A. Aerosol size distributions were measured between 10 and $1000 \mathrm{~nm}$ as a function of gas flow and impactor used. Small particles were counted 
by using an ultrafine condensation particle counter (UCPC) TSI 3025 A. The UCPC counter was very useful to observe the rapid formation of small particles following nucleation in the SOA formation.

\subsection{Experimental Methods and Procedures}

All photolysis experiments were performed in the QUAREC chamber using synthetic air and pure nitrogen. Prior to the experiments, an FTIR spectrum and UCPC scan were recorded to test possible background levels of aerosols and the cleanliness of air added to the reactor. All tests showed virtually no particle formation after the photolysis of background air for at least $30 \mathrm{~min}$, the time necessary for one experiment. The reactor was then partially evacuated and, with the reactor under reduced pressure ( $\sim 400 \mathrm{mbar}$ ), the nitroaromatic compounds were introduced into the chamber. The nitrocompound addition to the chamber was performed by using a special steel-glass heated inlet system in a flow of nitrogen/air. The nitroaromatic concentrations were $(2-10) \times 10^{13}$ molecule $\mathrm{cm}^{-3}$, which correspond to mixing ratios of $0.8-4$ ppmv ( 1 ppmv $=2.46 \times 10^{13}$ molecule $\mathrm{cm}^{-3}$ at $1 \mathrm{~atm}$ and $\left.298 \mathrm{~K}\right)$. In order to determine the wall loss rate, before starting the photolysis of the nitrophenols, FTIR spectra were recorded over a period of $15 \mathrm{~min}$ in the dark. FT-IR spectra were recorded at a spectral resolution of $1 \mathrm{~cm}^{-1}$ continuously during the experiment by co-adding 128 scans per spectrum over a time period of $2 \mathrm{~min}$. Prior to the start of the experiment, all computers connected to the instruments, used for recording data were timed in order to ensure a good data correlation.

Since it is known that the photolysis of nitrophenol is an important source of nitrous acid (HONO) in the gas phase $[11,12]$ and HONO can photolyze in the atmosphere leading to further $\mathrm{OH}$ radical formation, isoprene was injected as $\mathrm{OH}$ radical scavenger in some experiments in order to suppress interferences by the reaction of $\mathrm{OH}$ radicals with nitrophenols. The scavenger concentration was varied between (10-20) $\times 10^{13}$ molecule $\mathrm{cm}^{-3}$. Up to $4 \mathrm{ppmv}$ of NOx (NO with impurities of $2 \%$ as $\mathrm{NO}_{2}$ ) was added in three additional experiments to check for a potential effect of NOx on the aerosol formation yields.

\subsection{Chemicals}

All compounds used in the present study were obtained from Aldrich Co. (Sigma-Aldrich Chemie $\mathrm{GmbH}$, Munich, Germany) and used without further purification. Their purities were as follows: 2-nitrophenol, 98\%; 4-methyl-2-nitrophenol, 99\%; isoprene (liquid) 99\%. NO, 99.5\% (Messer-Griesheim); $\mathrm{NO}_{2}, 98 \%$ (Messer-Griesheim). Nitrogen and synthetic air $\left(20.5 / 79.5=\mathrm{O}_{2} / \mathrm{N}_{2} \%\right)$ were provided by Messer-Griesheim and Air Liquide, free of hydrocarbons.

\section{Results}

The SOA formation from the photolysis of nitrophenols is investigated for the first time in the present study. The experiments focused on the formation of SOA from the photolysis of 2-nitrophenol; however, some experiments were performed also for 4-methyl-2-nitrophenol.

Results presented in Figure 1 show that no particles are formed in the dark as can be seen in the first five SMPS scans. Additional experiments photolyzing only synthetic air in the chamber for approximately 30 min exhibited only very minor particle formation with less than 200 particle $\mathrm{cm}^{-3}$, which is negligible. Accordingly, particle formation shown in Figure 1 was solely resulting from the photolysis of nitrophenols. 


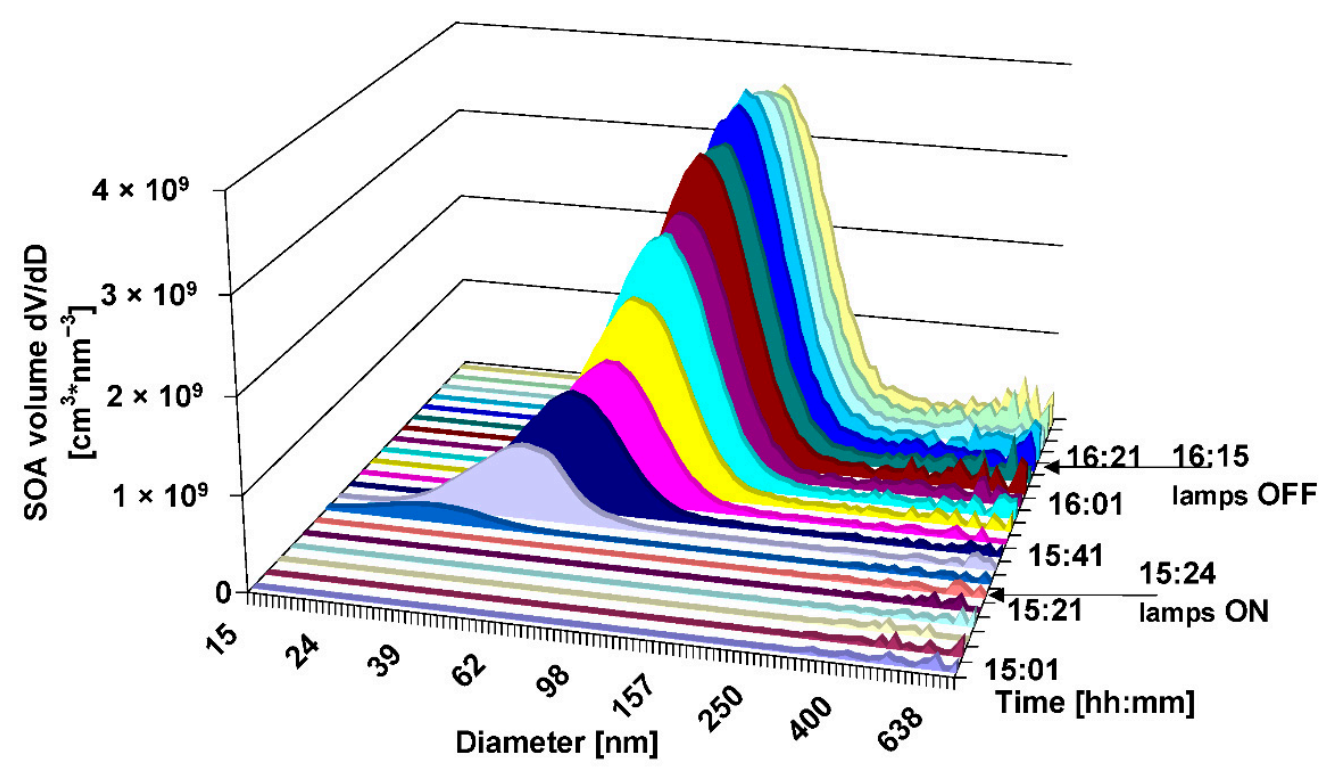

Figure 1. Example of SOA distribution during the photolysis of 0.8 ppmv of 2-nitrophenol in an experiment without $\mathrm{OH}$ radical scavenger and without NOx.

A fast formation of aerosols was detected just seconds after the photolysis lamps were switched on. This rapid formation was observed for both2-nitrophenolic compounds studied in this work. The first SMPS scans ranging from 10 to $750 \mathrm{~nm}$ particle size exhibited the formation of very small particles with a mean diameter of only 20 to $40 \mathrm{~nm}$. Figure 1 shows as an example for 2-nitrophenol photolysis, the formation of such small particles, and their growth. Significantly larger particles were observed later in the photolysis experiment, pointing to further coagulation of particles over time.

Figure 2 shows the concentration of 2-nitrophenol decreasing and the increase of the SOA mass concentration over time, according to the experiment presented in Figure 1. Rapid aerosol formation was observed in the simulation chamber. Figure 2 also indicates that only a small amount of 2-nitrophenol needs to be photolyzed to initiate aerosol formation. From this figure, it has been observed that photolytic conversion of only 10-15 ppbV of nitrophenol was enough to form aerosols that were detected by the UCPC. Quick particles formation was observed from photolysis of nitrophenol concentrations varying between $0.4-1.2 \mathrm{ppmv}$. Less than $1 \mathrm{~min}$ of photolysis time was necessary to measure a considerable amount of particles, leading to $1.0 \times 10^{5}$ particle $\mathrm{cm}^{-3}$, which is the maximum amount detected by the UCPC.

The concentration of nitrophenols used for the aerosol mass was corrected for wall losses. In Figure 1, there is an evident decay of the aerosol concentration when the photolysis lamps were switched off. The decay of the aerosol concentration could be also influenced by electrostatic deposition of the particles on the reactor walls. The decay of aerosol concentration measured at the end of the experiment was used to correct the aerosol mass when the aerosol yield was calculated. Usually, a correction of $10-15 \%$ for the aerosol mass was applied in the present study.

Using the aerosol volume distribution and assuming unity for the aerosol density, the aerosol mass formed in the photolysis experiments was calculated and plotted against the amount of reacted nitrophenols, where the slope represents the SOA yield (Figure 3). The aerosol mass linearly increased with increasing concentration of both 2-nitrophenol and 2-nitro-p-cresol (4-methyl-2-nitrophenol), and no big difference in the SOA yield was observed for the two nitrophenols in the examined concentration range. 


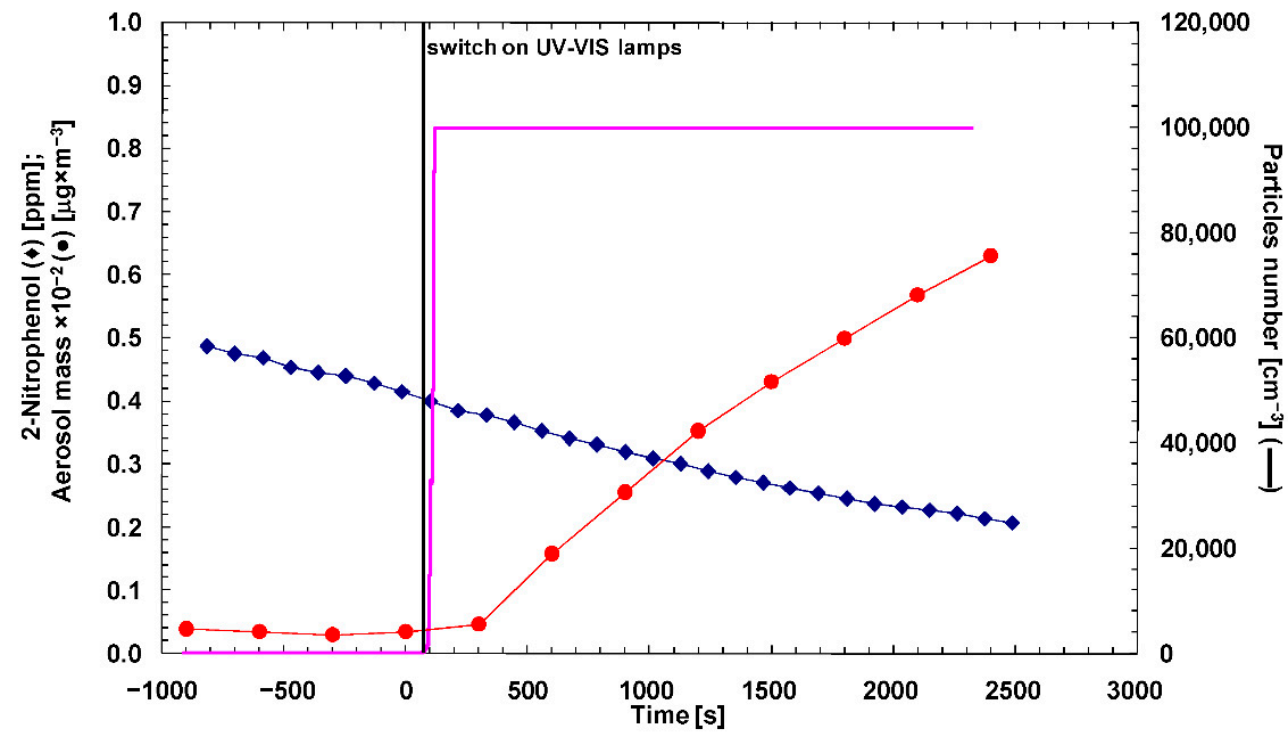

Figure 2. Concentration-time profile of 2-nitrophenol $(\bullet)$, aerosol mass $(\bullet)$ and SOA formation $(-)$ from aphotolysis experiment of $\sim 0.49 \mathrm{ppmv}$ of 2-nitrophenol without $\mathrm{OH}$ radical scavenger and $\mathrm{NOx}$.

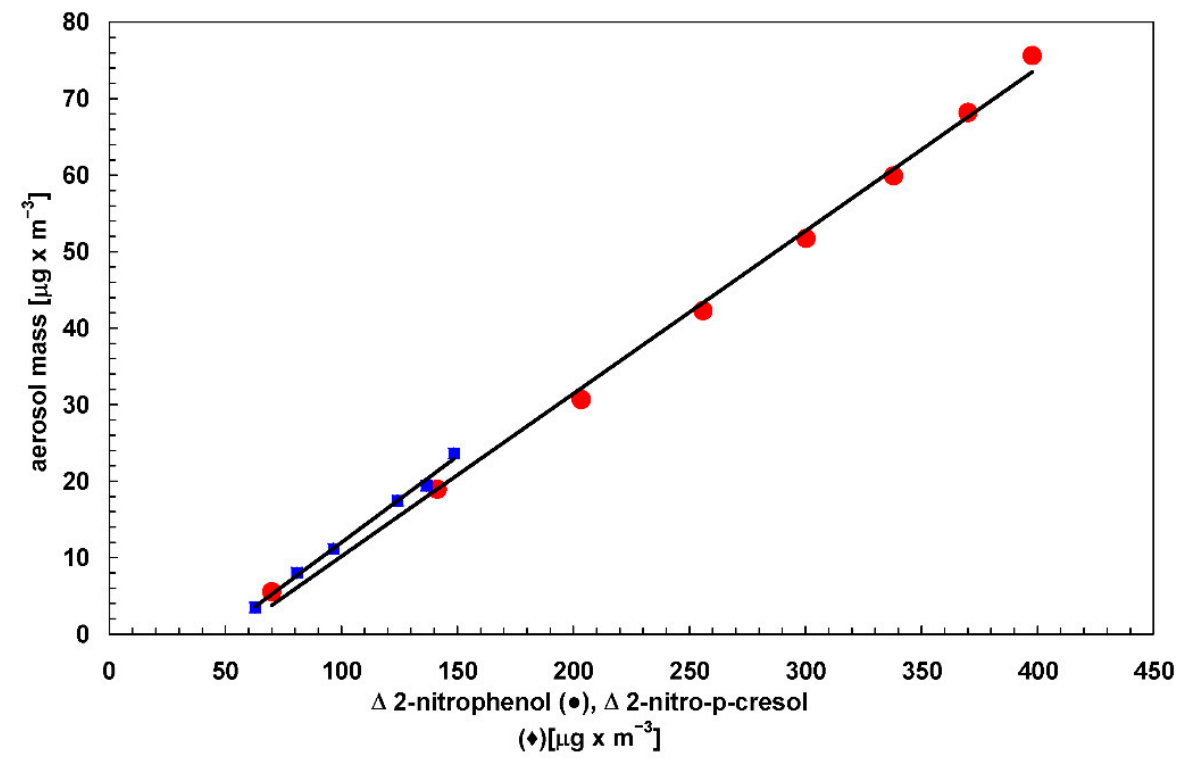

Figure 3. Aerosol mass yield as a function of reacted 2-nitrophenol ( $0.8 \mathrm{ppmv})(\bullet)$ and 2-nitro-p-cresol 0.95 ppmv ( $\square$ ). The aerosol mass yields were $22.2 \pm 1.15 \%$ for 2-nitrophenol and $24.4 \pm 0.95 \%$ for 2-nitro-p-cresol.

The aerosol mass yields from 2-nitrophenol photolysis are shown in Table 1. Three experiments at various concentrations of 2-nitrophenol were performed in this study for each investigated aspect. The SOA yields in the absence of the $\mathrm{OH}$ radical scavenger and additional NOx in the reaction mixture varied between $18 \%$ and $24 \%$. The yields are higher than those from 2-nitrophenol photolysis in the presence of the $\mathrm{OH}$ radical scavenger. Obviously, no SOA yield dependency was observed when the initial mixing ratio of 2-nitrophenol was varied from $0.49 \mathrm{ppmv}$ to $1.23 \mathrm{ppmv}$.

Table 1 shows the aerosol formation yields for three series of experiments as follows: (i) photolysis of 2-nitrophenol without $\mathrm{NOx}$ and $\mathrm{OH}$ scavenger, (ii) photolysis of 2-nitrophenol in the presence of $\mathrm{OH}$ radical scavenger, and (iii) photolysis of 2-nitrophenol in the presence of NOx. The highest aerosol yields were observed in the absence of the $\mathrm{OH}$ radical scavenger and NOx. This indicates 
either an additional aerosol formation from the $\mathrm{OH}$ radical reaction with 2-nitrophenol or an inhibitory effect of the $\mathrm{OH}$ radical scavenger and NOx on the SOA formation.

Table 1. Aerosol yield for the experiments of 2-nitrophenol photolysis under various conditions.

\begin{tabular}{|c|c|c|c|c|c|}
\hline $\begin{array}{c}\text { Experiments } \\
\text { Name }\end{array}$ & $\begin{array}{c}\text { 2-Nitrophenol } \\
\text { [ppmv] }\end{array}$ & $\begin{array}{c}\text { Aerosol Yield } \\
{[\%]}\end{array}$ & $\begin{array}{l}\text { Wall Loss Rate } \\
\left.\qquad \times 10^{5} \mathrm{~s}^{-1}\right]\end{array}$ & $\begin{array}{l}\text { Photolysis Rate } \\
\left.\qquad \times 10^{5} \mathrm{~s}^{-1}\right]\end{array}$ & Exp. Conditions \\
\hline 100305 & 0.80 & $22.2 \pm 1.15$ & $7.3 \pm 0.22$ & $10.3 \pm 0.49$ & \\
\hline 111005 & 0.49 & $21.3 \pm 0.98$ & $18.4 \pm 1.53$ & $9.3 \pm 0.44$ & \\
\hline 061105 & 1.23 & $19.6 \pm 1.64$ & $9.8 \pm 0.91$ & $8.4 \pm 0.60$ & \\
\hline 110305 & 1.12 & $6.9 \pm 1.00$ & $7.3 \pm 0.45$ & $5.8 \pm 0.29$ & scav. ${ }^{1}$ \\
\hline 120305 & 0.66 & $2.9 \pm 0.44$ & $7.4 \pm 2.60$ & $7.0 \pm 0.30$ & scav. ${ }^{1}$ \\
\hline 180305 & 1.14 & $7.5 \pm 2.10$ & $8.8 \pm 0.72$ & $4.6 \pm 0.10$ & scav. ${ }^{1}$ \\
\hline 060705_1 & 0.70 & -2 & $8.2 \pm 0.43$ & $7.3 \pm 0.78$ & NOx \\
\hline 060705_2 & 0.92 & -2 & $9.0 \pm 0.68$ & $6.5 \pm 0.24$ & NOx \\
\hline 070705 & 0.61 & -2 & $11.0 \pm 1.44$ & $9.7 \pm 0.58$ & NOx \\
\hline
\end{tabular}

${ }^{1}$ isoprene addition as $\mathrm{OH}$ radical scavenger, ${ }^{2}$ no aerosol yields calculation for high NOx experiments. The error in SOA yield was estimated from error propagation approach using the $2 \sigma$ standard deviation from the yield plots, errors from aerosol mass measurements and 2-nitrophenol concentrations. The errors from photolysis and wall deposition rates are $2 \sigma$ standard deviation from linear regression slopes.

Interferences on the aerosol formation from 2-nitrophenol photolysis could result from the SOA formed in the $\mathrm{OH}$ radical initiated oxidation of 2-nitrophenol. The $\mathrm{OH}$ radical is formed in the reaction system by the photolysis of HONO, which is known to be a product of 2-nitrophenol photolysis [11]. Bejan et al. (2007) have reported a very slow reaction between 2-nitrophenol and OH radicals [12], whereas the reaction of $\mathrm{OH}$ radicals with isoprene is very fast $\left(1 \times 10^{-10} \mathrm{~cm}^{3}\right.$ molecule $\mathrm{e}^{-1} \mathrm{~s}^{-1}$ at $\left.298 \mathrm{~K}\right)$ [42]. In order to suppress the reaction of nitrophenols with $\mathrm{OH}$ radicals and to investigate the $\mathrm{OH}$ radical effect on the SOA yields from 2-nitrophenol photolysis, isoprene (0.5-4 ppmv) was added as $\mathrm{OH}$ scavenger in a series of experiments. The isoprene added in these experiments was enough to scavenge $>97 \%$ of the $\mathrm{OH}$ radicals produced during the photolysis.

Figure 4 shows aerosol formation and growth during 2-nitrophenol photolysis and in the presence of isoprene as $\mathrm{OH}$ radical scavenger. The so-called banana type plot indicates the initial nucleation of the particles and further growing process of SOA. The particle size diameters increase during photolysis by uptake of freshly formed aerosols and condensable gas-phase products and/or reactants on the pre-existing SOA. At the end of the photolysis experiments, the size distribution and number concentration of particles were further measured to allow the calculation of the aerosol wall deposition rate in the dark. The decrease in particle concentration after photolysis is a result of combined processes, i.e., further aerosol coagulation and wall deposition.

SOA formation from 2-nitrophenol photolysis was almost fully suppressed in the presence of NOx. However, the UCPC instrument still showed the formation of a few hundred small particles, but it was not possible to calculate an aerosol yield. 


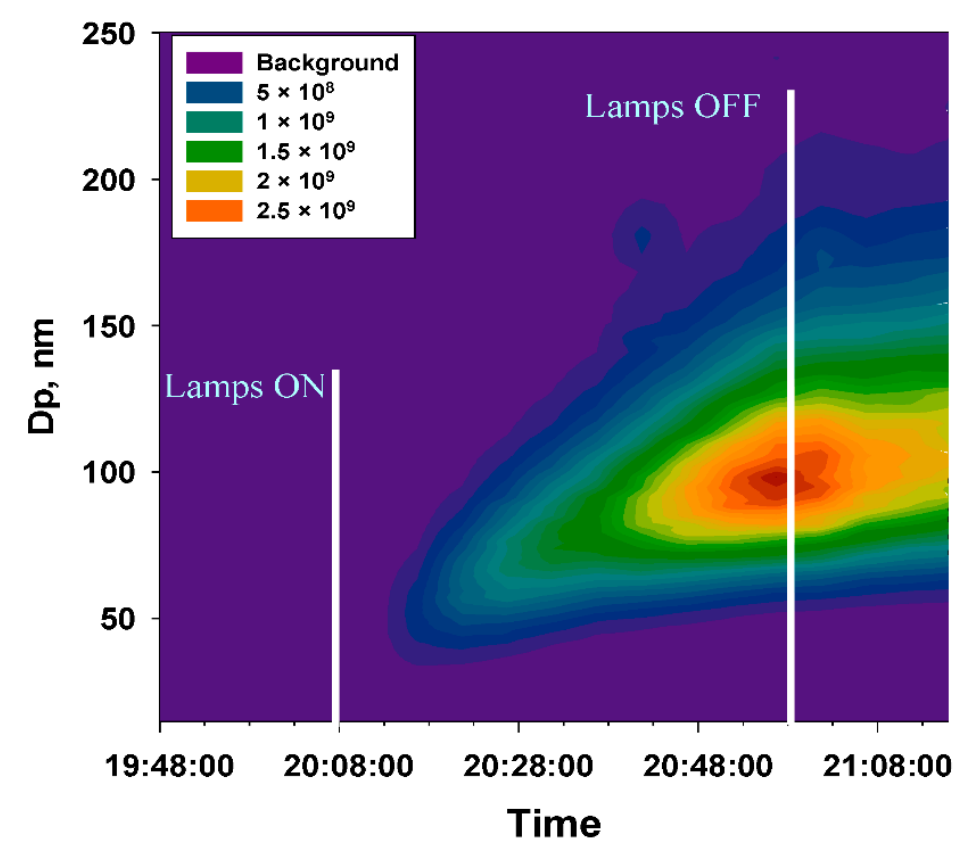

Figure 4. Size distribution and number concentration of particles forming during an experiment of 2-nitrophenol photolysis in the presence of isoprene as $\mathrm{OH}$ radical scavenger.

\section{Discussion}

\subsection{Expression for SOA Yield}

SOA yields have been calculated as the fraction of reactive organic gas compound (ROG) converted to aerosol mass (M) as defined by Odum et al. (1996) [43]. The fractional aerosol yield is given by the expression:

$$
\mathrm{Y}=\Delta \mathrm{M}_{0} / \Delta \mathrm{ROG}
$$

where $\Delta \mathrm{M}_{0}$ is the aerosol mass concentration produced by the photolysis of a known amount of nitrophenol, $\triangle$ ROG.

It has been proposed that SOA could be formed by partition of compounds between gas and particle phase and may be represented by the expression [43]:

$$
Y=M_{0} \sum_{i} \frac{\alpha_{i} k_{i}}{1+k_{i} M_{0}}
$$

where $Y$ is the total aerosol mass yield obtained from the photolysis of nitrophenols in terms of the individual single product stoichiometric coefficient $\alpha_{i}$, the gas/particle partition coefficient $K_{i}$, and the total aerosol mass $M_{0}$.

According to model suggested by Odum, Figure 5 shows the aerosol mass yield as a function of the SOA mass concentration for the photolysis of 2-nitrophenol and 4-methyl-2-nitrophenol, respectively. The lines in Figure 5 are the result of using the gas-phase partitioning model considering the presence of only one photolysis product in the gas and particle phase. The asymptotic aerosol yields approach values representing the aerosol masses rising infinitely. The stoichiometric $\alpha$ coefficient in the Odum's model representation strives to the experimentally determined aerosol formation yield. This indicates that the reaction product(s) formed in the photolysis process (has/have) extremely low volatility and will partition almost entirely to the particle phase. 


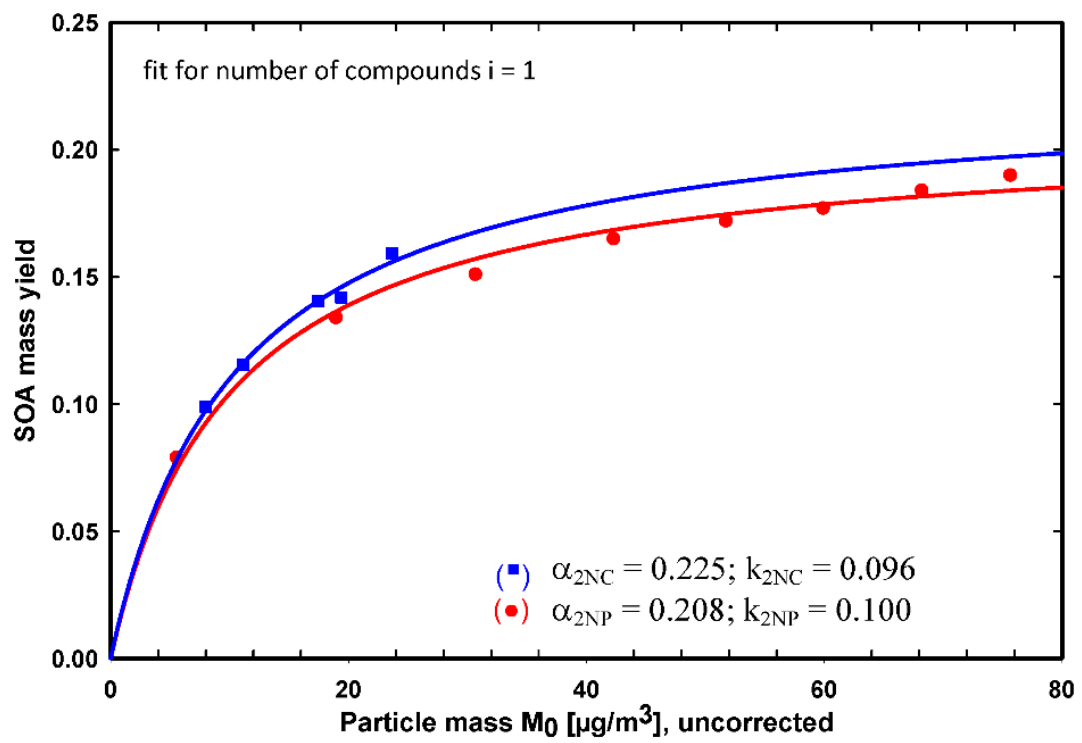

Figure 5. Estimation of the aerosol mass yield from the direct photolysis of 2-nitrophenol and 2-nitro-p-cresol applying Odum's partitioning model. The experimental aerosol mass yield is presented in Figure 3.

\subsection{Proposed Pathways to SOA Formation}

In the present study it was not possible to identify the products from the photolysis of 2-nitrophenol because of the low conversion of 2-nitrophenol to photolysis products making their detection by using FT-IR spectrometry impossible. Additionally, ELVOC expected products from the photolysis of 2-nitrophenol are obviously not favored being present in the gas phase. However, a possible mechanism for SOA formation is suggested in Figure 6.

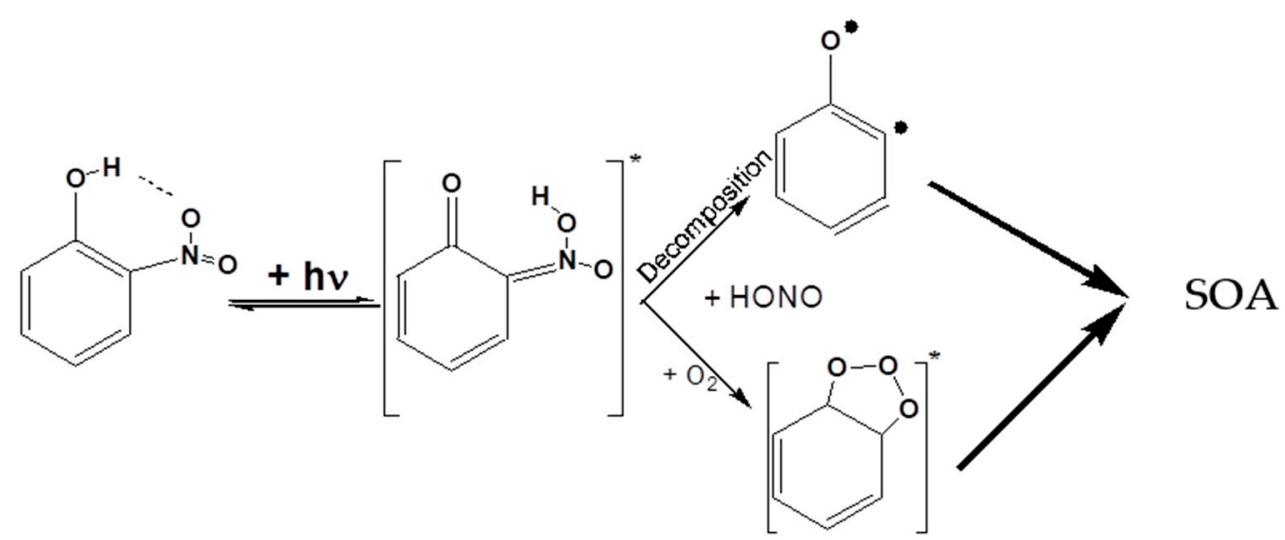

Figure 6. 2-nitrophenol photolysis mechanism suggested, explaining aerosol formation.

The proposed mechanism takes into account the instantaneous formation of HONO and the biradical formation route as well as the possible ozonide formation route [11]. The proposed biradical formation, most probably very reactive species, will undergo further chemical reactions with $\mathrm{O}_{2}$ and isomerization processes, which could lead to the formation of acids as has been proposed previously by Alif et al. (1991) [37] for aqueous solutions (Figure 7). Another possible reaction pathway for biradicals is their reaction with the nitrophenol reactant, leading to compounds with higher molecular mass and extremely low vapor pressure. In the presence of oxygen, the possible higher oxygenated compounds formed as gas phase products with low volatility will favor particle formation. 

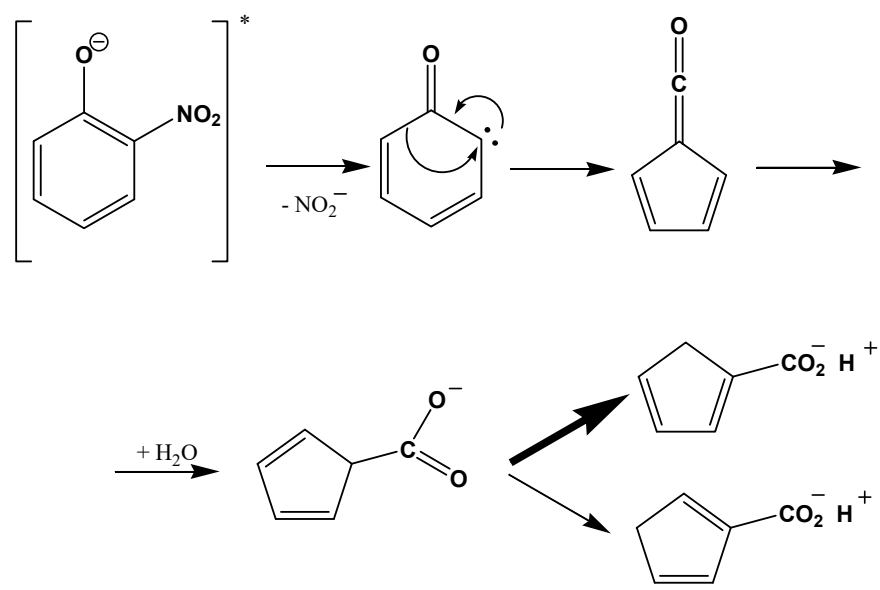

Figure 7. Carboxylic acids formation mechanism adapted from Alif et al. (1991) [37] in the aqueous phase to explain SOA precursor formation from nitrophenols photolysis.

Nitronic acid formation from the photolysis of 2-nitrophenol by thydrogen transfer from the hydroxyl functional group to the nitro group has been proposed by Bejan et al. (2006) [11] and Nagaya et al. (2006) [44]. Further, the biradical form resulted as a coproduct of HONO may be responsible for aerosol formation. In a study of the direct photolysis of 1-nitronaphtalene, Healy et al. (2012) suggested the formation of naphthoxy radicals and 2-nitronaphthol as gas-phase products. The evidence of a further self-reaction mechanism of naphthoxy radicals was obtained by using an aerosol time of flight mass spectrometer (ATOFMS) to study SOA composition. However, this study proposed also 2-nitronaphthol formation from nitronaphthalene direct photolysis. The 2-nitronaphthol photolysis could follow a photolysis mechanism as proposed in the present study in Figure 6 where the hydrogen transfer from the $\mathrm{OH}$ group to the nitro group is followed by HONO release and a biradical formation that easily could undergo dimmer formation by self-reaction [45].

The SOA yields for the compounds investigated are almost independent on concentration within the range of experimental errors, as shown in Figure 3. However, a small increase in the SOA formation yield can be seen in Figure 3 for the methylated compound and may be due to the increased reactivity of the methylated isomer.

\subsection{OH Radical Influence on Aerosol Formation}

Methylated 2-nitrophenols react with $\mathrm{OH}$ radicals with rate coefficients in the range (2.7-6.7) $\times 10^{-12} \mathrm{~cm}^{3}$ molecule ${ }^{-1} \mathrm{~s}^{-1}$ [12]. A series of experiments were performed in the presence of isoprene acting as $\mathrm{OH}$ radical scavenger to evaluate the effect of $\mathrm{OH}$ radicals on the SOA formation. Although particles formation has been reported for the photooxidation of isoprene [46-48], the tests performed in the QUAREC chamber have shown almost no aerosol formation at the isoprene concentrations used in the present study [49]. Up to $10^{3}$ particle $\mathrm{cm}^{-3}$ were obtained by $\mathrm{OH}$ radical initiated photooxidation of isoprene over a period of $30 \mathrm{~min}$ reaction time. These particles measured with the UCPC counter were produced slowly and are much less than $>10^{5}$ particle $\mathrm{cm}^{-3}$ extremely quickly formed from nitrophenol photolysis (Figure 2).

The data from Table 1 show a considerable decrease in the SOA yields when the $\mathrm{OH}$ radical scavenger is present in the reaction mixture. There was an unexpected high concentration of $\mathrm{OH}$ radicals; however, the presence of the $\mathrm{OH}$ radical scavenger produced a decrease in the SOA formation yield either due to the suppression of the reaction of nitrophenols with the $\mathrm{OH}$ radicals or due to the interaction of the scavenger with the intermediates formed from the photolysis of nitrophenols. In the literature, an effect of an $\mathrm{OH}$ radical scavenger on SOA formation from alkenes ozonolysis has been reported. The SOA yields are influenced by organic peroxy radicals resulting from the reactions of the $\mathrm{OH}$ radicals (formed by alkenes ozonolysis) with the scavenger [50,51]. Keywood et al. 
(2004) emphasized the effect of acylperoxy radicals resulting from the ozonolysis of alkenes, to contribute significantly to the SOA formation yield [51].

\subsection{NOx Effect on Aerosol Formation}

The present study on the direct photolysis of nitrophenols showed a strong inhibiting effect on the aerosol formation under initial high NOx conditions. The chemical degradation mechanism of the photooxidation of aromatic compounds is known to be influenced by the initial NOx concentration in the reaction system. Both theoretical and experimental studies established the effect of NOx on the photochemistry of aromatic compounds $[35,52]$ and, as a consequence, further the SOA formation [17,53-55]. In the absence of NOx, gas phase chemistry will lead to the highly oxygenated products, which are known precursors for SOA. On the other hand, NOx reactions will lead to organic nitrates and peroxynitrates, which are more volatile and are not favorable to new particle formation [55]. In the present study, it was not possible to verify the effect of NOx on SOA formation at levels of NOx prevailing in the troposphere. The analytical techniques employed in the present study did not allow gas phase product identification and performing experiments under NOx mixing ratios of 10-50 ppbv, which are typical for the urban atmosphere. However, Bardini (2006), in their study, performed in a EUPHORE chamber, where backgrounds of low levels of NOx are usually present, found a substantial amount of aerosols under the low to moderate concentration of NOx.

In a photooxidation study of 3-methyl-2-nitrophenol under atmospheric conditions, Derpmann et al. (2013) has found, employing newly developed capillary atmospheric pressure electron capture ionization mass spectrometry technique, products that have analyte ions with $\mathrm{m} / \mathrm{z}=137$ and $\mathrm{m} / \mathrm{z}=167$, respectively [56]. Their research investigations have identified a product with $\mathrm{m} / \mathrm{z}=167$ as 3-methyl-2-nitro-p-benzoquinone, while for $\mathrm{m} / \mathrm{z}=137$, a molecular formula $\mathrm{C}_{7} \mathrm{H}_{7} \mathrm{NO}_{2}$ is proposed. Although there is an evident inhibiting effect of SOA formation, it could only be speculated that the biradical compound formed through the photolysis of nitrophenols in the reaction with NOx could undergo formation of products with relatively high vapor pressure, which does not partition to particle phase. Also, the products that result under high NOx conditions could be photochemically inactive and to be unavailable in the SOA formation process. Further experimental work will be necessary to assess the effect of different NOx concentrations on the particle formation by direct photolysis of nitrophenols.

\section{Conclusions}

The formation of secondary organic aerosol (SOA) from direct photolysis of 2-nitrophenol and 4-methyl-2-nitrophenol was investigated in the present study for the first time. Rapid SOA formation has been observed for both nitrophenols investigated. No effect on the aerosol mass yield of the structural difference between methylated and non-methylated 2-nitrophenol has been observed. The direct photolysis of 2-nitrophenol in the absence of $\mathrm{NOx}$ and without $\mathrm{OH}$ radical scavenger in the reaction mixture indicated an aerosol formation yield in the range $18 \%-24 \%$.

The proposed photolytic degradation mechanism leading to SOA involves biradical formation during photolysis, which could react further with oxygen forming peroxy radicals, which will produce further highly oxygenated compounds. These compounds have low volatility and could form SOA.

The presence of the $\mathrm{OH}$ radical scavenger and the effect on the SOA yield has also been investigated. The effect of the initial NOx concentration on the SOA yield was tested for 2-nitrophenol photolysis. The corrections of the wall deposition of nitrophenols were performed and photolysis rates were measured.

A slightly higher SOA yield were calculated for higher 2-nitrophenol initial concentrations. The SOA yields measured in the absence of the $\mathrm{OH}$ radical scavenger were almost double those measured when isoprene acting as $\mathrm{OH}$ radical scavenger was present. The scavenger was proposed to act for suppressing the reactivity of the organic radical and, hence, suggest an inhibitory effect on the aerosol formation. In the direct photolysis of nitrophenols at elevated high NOx conditions, it would become obvious that the SOA formation is strongly inhibited possibly due to the formation of organic 
nitrates that possess higher vapor pressure and thus do not favor the SOA formation. Methylated nitrophenol photolysis does not produce a considerable difference on the SOA yield related to those SOA yields obtained from 2-nitrophenol photolysis.

A partition absorption model was used in the present study to provide additional qualitative information for the aerosol mass yield. The application of Odum's gas-phase partitioning model obtained the best fit of aerosol mass yield against SOA mass, assuming the presence of one aerosol precursor compound in both phases. The study proposed a photolysis degradation mechanism of nitrophenols to explain the experimental observations.

The present study has proven that the direct photolysis of nitrophenols is a potential source for aerosol formation in the atmosphere. Nitrophenols, present in the polluted atmosphere at mixing ratio almost of hundred pptv, are released during agricultural biomass burning. Their study becomes a priority to atmospheric research since their effect on climate and data provided by this study could be useful for atmospheric chemistry models. Further detailed investigations are needed to understand the inside mechanism of the nitrophenol photolysis. The study exhibited a very low reactant conversion through photolysis and a more sensitive technique will be necessary to help to identify the products formed during the photolysis of nitrophenol. The identification of intermediates responsible for aerosol formation could be possible by using different mass spectrometry techniques, helping to validate the proposed mechanism for the direct photolysis of these compounds.

Author Contributions: I.G.B., R.-I.O. and P.W. have full contributions to all stages from conceptualization to final draft preparation of the article. All authors have read and agreed to the published version of the manuscript.

Funding: The authors acknowledge the financial support provided by the European Union's Horizon 2020 research and innovation programme, through the EUROCHAMP-2020 Infrastructure, Activity Grant (grant agreement no. 730997) and UEFISCDI within the PN-III-P4-ID-PCE-2016-4-0807 (IGAC-CYCLO) and PN-III-P2-2.1-PED2019-4972 (PHONIC-HONO-SOA) projects.

Acknowledgments: The authors acknowledge the contribution to the projects EUROCHAMP-2020, IGAC-CYCLO, and PHONIC-HONO-SOA. The authors are indebted to the late Ian Barnes for his continuous support and supervision.

Conflicts of Interest: The authors declare no conflict of interest. The funders had no role in the design of the study; in the collection, analyses, or interpretation of data; in the writing of the manuscript, or in the decision to publish the results.

\section{References}

1. Finlayson-Pitts, B.J.; Pitts, J.N., Jr. Chemistry of the Upper and Lower Atmosphere: Theory, Experiments and Applications; Academic Press: San Diego, CA, USA; London, UK, 2000; pp. 1-969.

2. Seinfeld, J.H.; Pandis, S.N. Atmospheric Chemistry and Physics, from Air Pollution to Climate Change, 3rd ed.; John and Wiley Sons: Hoboken, NJ, USA, 2016.

3. Stockwell, W.R.; Lawson, C.V.; Saunders, E.; Goliff, W.S. A Review of Tropospheric Atmospheric Chemistry and Gas-Phase Chemical Mechanisms for Air Quality Modeling. Atmosphere 2012, 3, 1-32. [CrossRef]

4. Calvert, J.; Atkinson, R.; Becker, K.H.; Kamens, R.; Seinfeld, J.; Wallington, T.; Yarwood, G. The Mechanisms of the Atmospheric Oxidation of Aromatic Hydrocarbons; Oxford University Press: New York, NY, USA, 2002.

5. Derwent, R.G.; Jenkin, M.E.; Saunders, S.M.; Pilling, M.J. Photochemical Ozone Creation Potentials for Organic Compounds in Northwest Europe Calculated with a Master Chemical Mechanism. Atmos. Environ. 1998, 32, 2429-2441. [CrossRef]

6. Jenkin, M.E.; Derwent, R.G.; Wallington, T.J. Photochemical ozone creation potentials for volatile organic compounds: Rationalization and estimation. Atmos. Environ. 2017, 163, 128-137. [CrossRef]

7. Wang, S.; Newland, M.J.; Deng, W.; Rickard, A.R.; Hamilton, J.F.; Muñoz, A.; Ródenas, M.; Vázquez, M.M.; Wang, L.; Wang, X. Aromatic Photo-oxidation, A New Source of Atmospheric Acidity. Environ. Sci. Technol. 2020, 54, 7798-7806. [CrossRef] [PubMed]

8. Olariu, R.I.; Bejan, I.; Barnes, I.; Klotz, B.; Becker, K.H.; Wirtz, K. Rate Coefficients for the Gas-Phase Reaction of $\mathrm{NO}_{3}$ Radicals with Selected Dihydroxybenzenes. Int. J. Chem. Kin. 2004, 36, 577-583. [CrossRef] 
9. Pereira, K.L.; Hamilton, J.F.; Rickard, A.R.; Bloss, W.J.; Alam, M.S.; Camredon, M.; Ward, M.W.; Wyche, K.P.; Muñoz, A.; Vera, T.; et al. Insights into the Formation and Evolution of Individual Compounds in the Particulate Phase during Aromatic Photo-Oxidation. Environ. Sci. Technol. 2015, 49, 13168-13178. [CrossRef] [PubMed]

10. Wang, M.; Chen, D.; Xiao, M.; Ye, Q.; Stolzenburg, D.; Hofbauer, V.; Ye, P.; Vogel, A.L.; Mauldin, R.L.; Amorim, A.; et al. Photo-oxidation of aromatic hydrocarbons produces low-volatility organic compounds. Environ. Sci. Technol. 2020, 54, 13, 7911-7921. [CrossRef]

11. Bejan, I.; Abd El Aal, Y.; Barnes, I.; Benter, T.; Bohn, B.; Wiesen, P.; Kleffmann, J. The Photolysis of ortho-Nitrophenols: A new Gas Phase Source of HONO. Phys. Chem. Chem. Phys. 2006, 8, 2028-2035. [CrossRef]

12. Bejan, I.; Barnes, I.; Olariu, R.; Zhou, S.; Wiesen, P.; Benter, T. Investigations on the gas-phase photolysis and $\mathrm{OH}$ radical kinetics of methyl-2-nitrophenols. Phys. Chem. Chem. Phys. 2007, 9, 5686-5692. [CrossRef]

13. Samir, B.; Kalalian, C.; Roth, E.; Salghi, R.; Chakir, A. Gas-phase UV absorption spectra of pyrazine, pyrimidine and pyridazine. Chem. Phys. Lett. 2020, 751, 137469. [CrossRef]

14. Yan, J.; Wang, X.; Gong, P.; Wang, C. Nitrated polycyclic aromatic compounds in the atmospheric environment: A review. Crit. Rev. Environ. Sci. Technol. 2020. [CrossRef]

15. Ravishankara, A.R. Heterogeneous and Multiphase Chemistry in the Troposphere. Science 1997, 276, 1058-1065. [CrossRef]

16. Kanakidou, M.; Seinfeld, J.H.; Pandis, S.N.; Barnes, I.; Dentener, F.J.; Facchini, M.C.; Van Dingenen, R.; Ervens, B.; Nenes, A.; Nielsen, C.J.; et al. Organic Aerosol and Global Climate Modelling: A Review. Atmos. Chem. Phys. 2005, 5, 1053-1123. [CrossRef]

17. Martin-Reviejo, M.; Wirtz, K. Is Benzene a Precursor for Secondary Organic Aerosol? Environ. Sci. Technol. 2005, 39, 1045-1054. [CrossRef] [PubMed]

18. Nojima, K.; Fukaya, K.; Fukui, S.; Kanno, S. Studies on Photochemistry of Aromatic Hydrocarbons. II-The Formation of Nitrophenols and Nitrobenzene by the Photochemical Reaction of Benzene in the Presence of Nitrogen Monoxide. Chemosphere 1975, 2,77-82. [CrossRef]

19. Rippen, G.; Zietz, E.; Frank, R.; Knacker, T.; Klöpffer, W. Do Airborne Nitrophenols Contribute to Forest Decline? Environ. Technol. Lett. 1987, 8, 475-482. [CrossRef]

20. Isayev, O.; Rasulev, B.; Gorb, L.; Leszczynski, J. Structure-toxicity Relationships of Nitroaromatic Compounds. Mol. Divers. 2006, 10, 233-245. [CrossRef]

21. Grosjean, D. Atmospheric Fate of Toxic Aromatic Compounds. Sci. Total Environ. 1991, 100, 367-414. [CrossRef]

22. Harrison, M.A.J.; Barra, S.; Borghesi, D.; Vione, D.; Arsene, C.; Olariu, R.I. Nitrated Phenols in the Atmosphere: A Review. Atmos. Environ. 2005, 39, 231-248. [CrossRef]

23. Geissler, A.; Schöler, H.F. Gas Chromatographic Determination of Phenol, Methylphenols, Chlorophenols, Nitrophenols and Nitroquinones in Water. Wat. Res. 1994, 28, 2047-2053.

24. Herterich, R. Gas Chromatographic Determination of Nitrophenols in Atmospheric Liquid Water and Airborne Particulates. J. Chromat. 1991, 549, 313-324. [CrossRef]

25. Schüssler, W.; Nitschke, L. Nitrophenols in Precipitation. Chemosphere 2001, 42, 277-283. [CrossRef]

26. Lüttke, J.; Levsen, K. Phase Partitioning of Phenol and Nitrophenols in Clouds. Atmos. Environ. 1997, 31, 2649-2655. [CrossRef]

27. Voznakova, Z.; Podehradska, J.; Kohlickova, M. Determination of Nitrophenol in Soil. Chemosphere 1996, 33, 285-291. [CrossRef]

28. Kawamura, K.; Kaplan, I.R. Biogenic and Anthropogenic Organic Compounds in Rain and Snow Samples Collected in Southern California. Atmos. Environ. 1986, 20, 115-124. [CrossRef]

29. Tremp, J.; Mattrel, P.; Fingler, S.; Giger, W. Phenol and Nitrophenols as Tropospheric Pollutants: Emissions from Automobile Exhausts and Phase Transfer in the Atmosphere. Wat. Air Soil Pollut. 1993, 68, 113-123. [CrossRef]

30. Grosjean, D. Reactions of o-Cresol and Nitrocresol with NOx in Sunlight and with Ozone Nitrogen Dioxide Mixtures in the Dark. Environ. Sci. Technol. 1985, 19, 968-974. [CrossRef]

31. Atkinson, R.; Aschmann, S.M.; Arey, J. Reactions of $\mathrm{OH}$ and NO3 Radicals with Phenol, Cresols, and 2-Nitrophenol at $296 \pm 2$ K. Environ. Sci. Technol. 1992, 26, 1397-1403. [CrossRef] 
32. Bolzacchini, E.; Bruschi, M.; Hjorth, J.; Meinardi, S.; Orlandi, M.; Rindone, B.; Rosenbohm, E. Gas-Phase Reaction of Phenol with $\mathrm{NO}_{3}$. Environ. Sci. Technol. 2001, 35, 1791-1797. [CrossRef]

33. Olariu, R.I.; Klotz, B.; Barnes, I.; Becker, K.H.; Mocanu, R. FT-IR Study of the Ring-Retaining Products from the Reaction of $\mathrm{OH}$ Radicals with Phenol, o-, m- and p-Cresol. Atmos. Environ. 2002, 36, 3685-3697. [CrossRef]

34. Li, M.; Wang, X.; Lu, C.; Li, R.; Zhang, J.; Dong, S.; Yang, L.; Xue, L.; Chen, J.; Wang, W. Nitrated phenols and the phenolic precursors in the atmosphere in urban Jinan, China. Sci. Total Environ. 2020, 714, 136760. [CrossRef] [PubMed]

35. Hidy, G.M. Atmospheric Chemistry in a Box or a Bag. Atmosphere 2019, 10, 401. [CrossRef]

36. Olariu, R.I.; Barnes, I.; Bejan, I.; Arsene, C.; Vione, D.; Klotz, B.; Becker, K.H. FT-IR product study of the reactions of NO3 radicals with ortho-, meta- and para-cresol. Environ. Sci. Technol. 2013, 47, 7729-7738. [CrossRef] [PubMed]

37. Alif, A.; Pilichowski, J.-F.; Boule, P. Photochemistry and Environment XIII: Phototransformation of 2-Nitrophenol in Aqueous Solution. J. Photochem. Photobiol. A Chem. 1991, 59, 209-219. [CrossRef]

38. Chen, B.; Chun, Y.; Khang, G.N. Direct Photolysis of Nitroaromatic Compounds in Aqueous Solutions. J. Environ. Sci.-China 2005, 17, 598-604.

39. Bardini, P. Atmospheric Oxidation of Dimethylphenols and Nitrophenols. Ph.D. Thesis, University of Cork, Cork, Ireland, 2005.

40. Zádor, J.; Turányi, T.; Wirtz, K.; Pilling, M.J. Measurement and investigation of chamber radical sources in the European Photoreactor (EUPHORE). J. Atmos. Chem. 2006, 55, 147-166. [CrossRef]

41. Barnes, I.; Becker, K.H.; Mihalopoulos, N. An FT-IR Product Study of the Photo-Oxidation of Dimethyl Disulfide. J. Atmos. Chem. 1994, 18, 267-289. [CrossRef]

42. Atkinson, R. Gas-phase tropospheric chemistry of biogenic volatile organic compounds: A review. Atmos. Environ. 2003, 37, 197-219. [CrossRef]

43. Odum, J.R.; Hoffmann, T.; Bowman, F.; Collins, D.; Flagan, R.C.; Seinfeld, J.F. Gas/Particle Partitioning and Secondary Organic Aerosol Yields. Environ. Sci. Technol. 1996, 30, 2580-2585. [CrossRef]

44. Nagaya, M.; Kudoh, S.; Nakata, M. Infrared Spectrum and Structure of aci-nitro Form of 2-Nitrophenol in a Low-temperature Argon Matrix. Chem. Phys. Lett. 2006, 427, 67-71. [CrossRef]

45. Healy, R.M.; Chen, Y.; Kourtchev, I.; Kalberer, K.; O'Shea, D.; Wenger, J.C. Rapid Formation of Secondary Organic Aerosol from the Photolysis of 1-Nitronaphthalene: Role of Naphthoxy Radical Self-reaction. Environ. Sci. Technol. 2012, 46, 11813-11820. [CrossRef] [PubMed]

46. Claeys, M.; Graham, B.; Vas, G.; Wang, W.; Vermeylen, R.; Pashynska, V.; Cafmeyer, J.; Guyon, P.; Andreae, M.O.; Artaxo, P.; et al. Formation of Secondary Organic Aerosols through Photooxidation of Isoprene. Science 2004, 303, 1173-1176. [CrossRef] [PubMed]

47. Kroll, J.H.; Ng, N.L.; Murphy, S.M.; Flagan, R.C.; Seinfeld, J.H. Secondary Organic Aerosol Formation from Isoprene Photooxidation. Environ. Sci. Technol. 2006, 40, 1869-1877. [CrossRef] [PubMed]

48. Surratt, J.D.; Murphy, S.M.; Kroll, J.H.; Ng, N.L.; Hildebrandt, L.; Sorooshian, A.; Szmigielski, R.; Vermeylen, R.; Maenhaut, W.; Claeys, M.; et al. Chemical Composition of Secondary Organic Aerosol Formed from the Photooxidation of Isoprene. J. Phys. Chem. A 2006, 110, 9665-9690. [CrossRef] [PubMed]

49. Bejan, I.; Schürmann, A.; Barnes, I.; Benter, T. Kinetics of the gas-phase reactions of OH radicals with a series of trimethylphenols. Int. J. Chem. Kinet. 2012, 44, 117-124. [CrossRef]

50. Docherty, K.S.; Ziemann, P.J. Effects of Stabilized Criegee Intermediate and $\mathrm{OH}$ Radical Scavengers on Aerosol Formation from Reactions of beta-Pinene with $\mathrm{O}_{3}$. Aerosol Sci. Technol. 2003, 37, 877-891. [CrossRef]

51. Keywood, M.D.; Kroll, J.H.; Varutbangkul, V.; Bahreini, R.; Flagan, R.C.; Seinfeld, J.H. Secondary Organic Aerosol Formation from Cyclohexene Ozonolysis: Effect of OH Scavenger and the Role of Radical Chemistry. Environ. Sci. Technol. 2004, 38, 3343-3350. [CrossRef]

52. Volkamer, R.; Klotz, B.; Barnes, I.; Imamura, T.; Wirtz, K.; Washida, N.; Becker, K.H.; Platt, U. OH-Initiated Oxidation of Benzene. Part I. Phenol Formation under Atmospheric Conditions. Phys. Chem. Chem. Phys. 2002, 4, 1598-1610. [CrossRef]

53. Hurley, M.D.; Sokolov, O.; Wallington, T.J.; Takekawa, H.; Karasawa, M.; Klotz, B.; Barnes, I.; Becker, K.H. Organic aerosol formation during the atmospheric degradation of toluene. Environ. Sci. Technol. 2001, 35, 1358-1366. [CrossRef] 
54. Song, C.; Na, K.; Cocker, D.R. Impact of the Hydrocarbon to NOx Ratio on Secondary Organic Aerosol Formation. Environ. Sci. Technol. 2005, 39, 3143-3149. [CrossRef]

55. Tsiligiannis, E.; Hammes, J.; Salvador, C.M.; Mentel, T.F.; Hallquist, M. Effect of NOx on 1,3,5-trimethylbenzene (TMB) oxidation product distribution and particle formation. Atmos. Chem. Phys. 2019, 19, 15073-15086. [CrossRef]

56. Derpmann, V.; Mueller, D.; Bejan, I.; Sonderfeld, H.; Wilberscheid, S.; Koppmann, R.; Brockmann, K.J.; Benter, T. Capillary atmospheric pressure electron capture ionization (cAPECI): A highly efficient ionization method for nitroaromatic compounds. J. Am. Soc. Mass Spectrom. 2014, 25, 329-342. [CrossRef] [PubMed]

Publisher's Note: MDPI stays neutral with regard to jurisdictional claims in published maps and institutional affiliations.

(C) 2020 by the authors. Licensee MDPI, Basel, Switzerland. This article is an open access article distributed under the terms and conditions of the Creative Commons Attribution (CC BY) license (http://creativecommons.org/licenses/by/4.0/). 